chiếm $85,6 \%$, thực hành đúng là $70 \%$, vừa có kiến thức, vừa thực hành đúng là $62,9 \%$. Trong đó Học sinh nữ có kiến thức, thực hành đúng cao gấp 2,37 lần học sinh nam $(p=0,001)$. Học sinh ở thành thị có kiến thức, thực hành đúng cao gấp 2,32 lân học sinh ở nông thôn $(p=0,001)$

\section{TÀI LIÊU THAM KHẢO}

1. WHO (2000), Global data on dental caries prevalence (DMFT) in children aged 12 years, pp.1-9.

2.Petersen PE (2008), World Health Organization global policy for improvement of oral health - World Health Assembly 2007, International Dental Journa, 58(3), pp.115-121.
3.Governement of south Australia (2010), South Australia's oral health plan 2010-2017, pp.1-26.

4. Trân Văn Trường, Trinh Đình Hải (2001),"Kết quả điều tra sức khỏe răng miệng toàn quốc ớ Việt Nam 1999 - 2000", Tạp chí Y học Việt Nam, (10), tr. 8-21.

5. Võ Trương Như Ngọc (2013), Răng trẻ em, NXB Giáo dục Việt Nam, tr.9-127.

6. Phan Kim Trọng (2017), Nghiên cứu tỷ lệ sâu răng của học sinh tiểu hoc.

7. Vũ Văn Tâm (2017), Tỷ lệ sâu răng của trẻ trong Vĩnh Tường.

8. Viện Răng Hàm Mặt quốc gia (2001), Điều tra dịch tễ học bệnh sâu răng tại Việt Nam.

9. Trương Manh Dũng, Vũ Manh Tuấn (2010), Thực trạng bệnh răng miệng và một số yếu tố liên quan ở trẻ 4-8 tuổi tại 5 tỉnh thành của Việt Nam năm 2010, Tạp chí Y học thực hành (797), Số 12/2011.

\title{
THỰC TRANG VÀ MộT SỐ YẾU TỐ LIÊN QUAN ĐẾN ĐÁP ỨNG ĐIỀU TRI THUÛ́C ARV CỦA NGƯỜI BÊ̂NH TẠI HAI CO' SỞ CHĂM SÓC ĐIỀU TRI HIV/AIDS TỈNH YÊN BÁI NĂM 2021
}

\section{TÓM TẮT.}

Mục tiêu: Mô tả thực trạng đáp ứng điều trị thuốc ARV và xác định một sổ yếu tố liên quan đến đáp ứng điều trị của người bệnh tại hai cơ sở chăm sóc điêu trị tỉnh Yền Bái năm 2021. Đối tượng và phương pháp nghiên cứu: Nghiên cứu mô tả cắt ngang triển khai tứ 01/01/2021 đến 31/8/2021 với 399 người bệnh nhiễm HIV trên 18 tuổi, đang được quản lý và điều trị ARV tại cơ sở chăm sóc điều trị HIV/AIDS Bệnh viên đa khoa khu vực Nghĩa Lộ và Trung tâm y tế thành phố Yên Bái, tỉnh Yên Bái. Kết quả. Trong tổng số người bệnh đang được quản lý và điều trị $A R V, 96,2 \%$ người bệnh đáp ứng điêu trị thuốc ARV, trong đó $100 \%$ người bệnh sử dụng phác đồ bậc 2 có đáp ứng điều trị. Các yểu tố liên quan đến đáp ứng điều trị bao gồm: trình độ học vấn Trung học phổ thông $(\mathrm{aOR}=11 ; 95 \% \mathrm{CI}$ : $2,6-46,9)$, thời gian điều trị ARV $(\mathrm{aOR}=1,3 ; 95 \% \mathrm{CI}$ : $1,06-1,6)$ và tuân thủ điều trị $(\mathrm{aOR}=5,6 ; 95 \% \mathrm{CI}: 1,4-$ 22,6). Kết luâan. Cần tăng cường quán lý, hố trợ điều trị và tăng cường tư vấn để nâng cao sự tuân thủ điều trị, từ đó giúp bệnh nhân có đáp ứng điêu trị ARV tốt hơn.

Tư khóa. HIV/AIDS, ARV, đáp ứng điều trị, Yên Bái.

\section{SUMMARY}

STATUS AND SOME FACTORS RELATED TO ARV TREATMENT RESPONSE OF PATIENTS

\footnotetext{
${ }^{1}$ Trung tâm Kiểm soát bệnh tật tỉnh Yên Bái

${ }^{2}$ Trường Đại học Y Hà Nội

Chịu trách nhiệm chính: Đoàn Thị Huệ

Email: huedpyb@gmail.com

Ngày nhận bài: 2.8.2021

Ngày phản biện khoa học: 29.9.2021

Ngày duyệt bài: 7.10.2021
}

Đoàn Thị Huệ ${ }^{1}$, Lê Vĩnh Giang ${ }^{2}$

\section{AT TWO HIV/AIDS TREATMENT FACILITIES} IN YEN BAI PROVINCE IN 2021

Objective. Describe the status of response to antiretroviral therapy and identify some factors related to the treatment response of patients at two HIV/AIDS treatment facilities in Yen Bai province in 2021. Subjects and methods. A cross-sectional descriptive study was produced from January 1, 2021 to August 31, 2021 among 399 HIV-infected patients over 18 years old, managed and received ART at the HIV/AIDS care and treatment facility - Nghia Lo area general hospital and Yen Bai city health center, Yen Bai province. Results. Of the total number of HIV-infected patients managed and received antiretroviral therapy (ART), 96.2\% of patients responded to ART, in which $100 \%$ of patients using second-line regimens respond to treatment. Factors related to treatment response include: high school education level $(\mathrm{aOR}=11 ; 95 \% \mathrm{CI}$ : 2.6-46.9), duration of ART (aOR=1.3; 95\%CI: $1.06-$ 1.6) and treatment adherence $(\mathrm{aOR}=5.6 ; 95 \% \mathrm{CI}: 1.4-$ 22.6). Conclusion. It is necessary to strengthen management, treatment support and counseling to improve treatment adherence, thereby helping patients have a better treatment response to ART.

Keywords. HIV/AIDS, ARV, treatment response, Yen Bai.

\section{I. ĐĂT VẤN ĐỀ}

Hiện nay, điều trị bằng thuốc kháng vi rút HIV (ARV) là một trong những biện pháp quan trọng và hiệu quả để giảm lây nhiễm HIV. Điêu trị thuốc ARV nhằm ức chế sự nhân lên của vi rút, kìm hãm lượng vi rút trong máu ở mức thấp nhất, làm giảm đáng kể tỷ lệ mắc và tử vong, giảm nguy cơ lây truyền HIV cải thiện hệ miễn dịch[1], 
giúp cơ thể bệnh nhân ngăn chặn hoặc giảm tác hại của nhiễm trùng cơ hội[2].

Theo thống kê của Chương trình phối hợp của Liên Hợp Quốc về HIV/AIDS (UNAIDS) năm 2020, trên toàn thế giới khoảng 38,0 triệu người nhiễm HIV, trong đó có khoảng $73 \%$ người nhiễm HIV đang điều trị thuốc kháng vi rút HIV[3]. Tại Việt Nam kể từ ca nhiễm HIV đầu tiên phát hiện vào năm 1990, cả nước có khoảng hơn 200.000 người nhiễm HIV hiện đang còn sống và hơn 100.000 người nhiễm HIV đã tử vong. Điều trị ARV được triển khai tai 63 tỉnh thành phố đã điều tri cho hơn 140.000 bệnh nhân, trong đó có 12.750 bệnh nhân mới điều trị trong năm 2019[4]. Tỷ lệ người bệnh được điều trị ARV kiểm soát được tải lượng virus ở mức thấp và ổn định trên cả nước đạt 93\%, vượt chỉ tiêu của mục tiêu thứ 3 trong mục tiêu 90-90-90 nhằm kết thúc đại dịch AIDS vào năm 2030 [4].

Yên Bái là một trong 10 tỉnh có tỷ lệ hiện nhiễm HIV/AIDS cao nhất cả nước với 160/173 xã phường có người nhiễm, số người nhiếm HIV hiện còn sống được quản lý là 2.196 người, trong đó có khoảng 1.800 người đang được điêu trị [5]. Cho đến nay, tỉnh Yên Bái chưa có nghiên cứu nào về điều trị thuốc $A R V$ cho người nhiễm HIV. Do đó, để có cơ sở cho việc xây dựng các chiến lược phòng chống HIV/AIDS cho những năm tiếp theo, chúng tôi tiến hành nghiên cứu nhằm mô tả thực trạng đáp ứng điều trị thuốc $A R V$ và xác định một số yếu tố liên quan đến đáp ứng điều trị của người bênh tai hai cơ sở chăm sóc điều trị Bệnh viện đa khoa khu vực Nghĩa Lộ và Trung tâm y tế thành phố Yên Bái.

\section{II. ĐỐI TƯƠ'NG VÀ PHƯƠNG PHÁP NGHIÊN CỨU \\ 2.1. Thời gian và địa điểm nghiên cứu \\ - Thời gian nghiên cứu: Từ 01/01/2021 đến 31/8/2021; \\ - Địa điểm: Cơ sở chăm sóc điều trị HIV/AIDS \\ - Bệnh viện đa khoa khu vực Nghĩa Lộ và Trung tâm Y tế thành phố Yên Bái.}

2.2. Đối tượng nghiên cứu. Tất cả các bệnh nhân nhiếm HIV đang được quản lý và điêu trị ARV đủ 18 tuổi trở lên, điều trị thuốc ARV từ 6 tháng trở lên, được làm xét nghiệm tải lượng vi rút trong 12 tháng tính đến ngày phỏng vấn và đồng ý tham gia nghiên cứu.

Tiêu chuẩn loại trừ: (1) Vắng mặt tại thời điểm nghiên cứu, (2) Không có khả năng đọc, hiểu, trả lời, nhớ lại và ra quyết định thỏa thuận nghiên cứu.

2.3. Thiết kế nghiên cứu. Mô tả cắt ngang. 2.4. Cỡ mấu và phương pháp chọn mẫu
- Cõ mẫu: 399 người nhiễm HIV/AIDS đang được quản lý và điều trị ARV.

- Phương pháp chọn mẫu: Chọn toàn bô người nhiễm HIV/AIDS đáp ứng tiêu chuẩn tuyển chọn của nghiên cứu.

\subsection{Biến số, chỉ số nghiên cứu}

- Biến phụ thuộc: Mức độ đáp ứng điều trị ARV của người nhiểm HIV được xác định dựa vào kết quả xét nghiệm tải lượng vi rút: Có đáp ứng điều trị khi kết quả xét nghiệm tải lượng vi rút của bệnh nhân dưới $200 \mathrm{cp} / \mathrm{ml}$ và không đáp ứng điều trị khi kết quả xét nghiệm tải lượng vi rút của bệnh nhân từ $200 \mathrm{cp} / \mathrm{ml}$ trở lên.

- Biến số độc lập: nhóm tuổi, giới tính, trình độ học vấn, tác dụng phụ, thời gian điều trị ARV, tuân thủ điều trị và mức độ nhận được sự hỗ trợ của cán bộ y tế.

2.6. Quản lý và phân tích số liệu. Số liệu được nhập, làm sạch bằng phần mềm Epidata 3.1 và xử lý số liệu bằng phần mềm STATA 16.0. Biến số định tính được biểu diễn dưới dạng tần số, tỷ lệ phần trăm. Phân tích hồi quy logistic đơn biến và đa biến được sử dụng để xác định một số yếu tố liên quan đến đáp ứng điều trị ARV của người bệnh, thông qua tỷ số chênh (OR), hệ số hiệu chỉnh (aOR) và khoảng tin cây $95 \%(95 \% \mathrm{CI})$ với mức ý nghĩa thống kê $p<0,05$.

2.7. Đạo đức nghiên cứu. Đề cương nghiên cứu được thông qua bởi Hội đồng xét duyệt đề cương tốt nghiệp Sau đại học, trường Đại học $Y$ Hà Nội. Nghiên cứu được sự đồng ý tham gia của hai cơ sở chăm sóc điêu trị ARV Bệnh viện đa khoa khu vực Nghĩa Lộ và Trung tâm y tế thành phố Yên Bái. Người bệnh tham gia được cung cấp thông tin và tự nguyện đồng ý tham gia nghiên cứu. Nghiên cứu sử dụng mã số và không ghi nhận thông tin định danh của người bệnh.

III. KẾT QUẢ NGHIÊN CỨU

\subsection{Thông tin chung}

Bảng 1. Thông tîn chung của người bệnh $(n=399)$

\begin{tabular}{|c|c|c|}
\hline \multirow[b]{2}{*}{ Đặc trưng } & \multicolumn{2}{|c|}{ Chung $(n=399)$} \\
\hline & $\begin{array}{c}\text { Tân số } \\
\text { (n) }\end{array}$ & $\begin{array}{l}\text { Tỷ lế } \\
(\%)\end{array}$ \\
\hline Nhóm tuối: $18-29$ tuối & 28 & 7,0 \\
\hline $30-39$ tuối & 122 & 30,6 \\
\hline $40-49$ tuối & 203 & 50,9 \\
\hline Từ 50 tuối trở lên & 46 & 11,5 \\
\hline Giới tính: Nam & 244 & 61,2 \\
\hline$N \tilde{u}$ & 155 & 38,8 \\
\hline Dân tộc: Kinh & 269 & 67,4 \\
\hline Khác & 130 & 32,6 \\
\hline Trình độ họ & vấn & \\
\hline
\end{tabular}




\begin{tabular}{|c|c|c|}
\hline Dưới Trung học phố thông & 101 & 25,3 \\
\hline Trung học phố thông & 183 & 70,9 \\
\hline Cao đắng/Đại học/Sau đại học & 15 & 3,8 \\
\hline
\end{tabular}

Kết quả cho thấy trong tống số 399 người bệnh tham gia nghiên cứu, phân lớn ở độ tuổi 4049 chiếm $50,8 \%$, chủ yếu là nam giới $(61,2 \%)$ và có trình độ học vấn Trung học phổ thông (70,9\%).

\section{2. Đánh giá đáp ứng điêuu trị ARV}

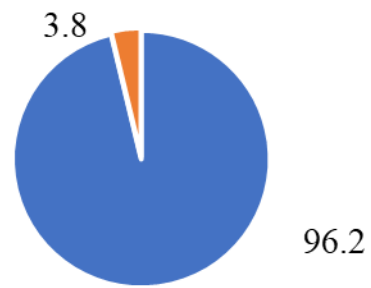

- Đáp ứng điều trị - Không đáp ứng điều trị

\section{Hình 1: Thực trạng đáp ứng điều trị ARV $(n=399)$}

Trong 12 tháng qua, có $96,2 \%$ người bệnh có đáp ứng với điều trị ARV, chỉ có 3,8\% không đáp ứng với điều trị ARV.

Bảng 2: Thực trạng đáp ứng điều trị ARV theo thời gian điều trị $(n=399)$

3.3. Một số yếu tố liên quan đến đáp ứng điêu trị ARV

Bảng 4: Một số yêu tố liên quan đến đáp ứng điều trị của người bệnh (n=399)

\begin{tabular}{|c|c|c|c|c|}
\hline \multirow{2}{*}{ Đặc điểm } & \multicolumn{2}{|c|}{ Đơn biến } & \multicolumn{2}{|l|}{ Đa biến } \\
\hline & OR (95\% CI) & $\mathbf{p}$ & aOR (95\% CI) & $\mathbf{p}$ \\
\hline \multicolumn{5}{|c|}{ Nhóm tuối (với 18-29 tuối) } \\
\hline $30-39$ tuối & $1,8(0,3-9,8)$ & 0,5 & - & - \\
\hline $40-49$ tuối & $2,2(0,4-10,9)$ & 0,4 & - & - \\
\hline Từ 50 tuối trở lên & $3,5(0,3-37,4)$ & 0,3 & - & - \\
\hline \multicolumn{5}{|l|}{ Giới (với Nam) } \\
\hline Nữ & $2,6(0,7-9,4)$ & 0,1 & - & - \\
\hline \multicolumn{5}{|c|}{ Trình độ học vấn (với Dưới THPT) } \\
\hline THPT & $11,4(3,1-41,8)$ & $<0,001$ & $11(2,6-46,9)$ & 0,001 \\
\hline Cao đằng, Đại học trở lên & $1,7(0,2-14,3)$ & 0,6 & $0,9(0,1-10,0)$ & 0,9 \\
\hline Thời gian điều trị ARV (năm) & $1,2(1,02-1,4)$ & 0,03 & $1,3(1,06-1,6)$ & 0,01 \\
\hline \multicolumn{5}{|c|}{ Tuân thủ điều trị (với Không tuân thủ) } \\
\hline Có tuân thủ & $6,1(1,9-19,6)$ & 0,002 & $5,6(1,4-22,6)$ & 0,02 \\
\hline \multicolumn{5}{|c|}{ Có gặp tác dụng phụ (với có gặp tác dụng phụ) } \\
\hline Không gặp tác dụng phụ & $4,3(1,5-12,1)$ & 0,006 & $3,2(0,9-11,8)$ & 0,07 \\
\hline \multicolumn{5}{|c|}{ Mức độ nhận được hố trợ của CBYT (với với thỉnh thoảng) } \\
\hline Thường xuyên & $5,6(2,0-16,0)$ & 0,001 & $2,8(0,7-10,7)$ & 0,1 \\
\hline
\end{tabular}

THPT: Trung học phố thông; CBYT: cán bộ y tế.

Phân tích hồi quy logistic đa biến cho thấy người bệnh có trình độ học vấn là trung học phổ thông có khả năng đáp ứng điều trị cao hơn gấp 11 lần so với người bệnh có học vấn dưới trung học phổ thông. Người bệnh có thời gian điều trị ARV càng lâu thì càng có đáp ứng điêuu trị ARV

\begin{tabular}{|c|c|c|c|c|}
\hline \multirow{2}{*}{$\begin{array}{c}\text { Thời gian điêu } \\
\text { trị ARV }\end{array}$} & \multicolumn{2}{|c|}{$\begin{array}{c}\text { Đáp ứng } \\
\text { điều trị ARV }\end{array}$} & \multicolumn{2}{c|}{$\begin{array}{c}\text { Không đán } \\
\text { ứng điêuu } \\
\text { trị ARV }\end{array}$} \\
\cline { 2 - 5 } & $\mathbf{n}$ & $\mathbf{\%}$ & $\mathbf{n}$ & $\mathbf{\%}$ \\
\hline $\begin{array}{c}\text { Từ } 5 \text { năm trở } \\
\text { xuống }\end{array}$ & 121 & 93,1 & 9 & 6,9 \\
\hline $6-10$ năm & 186 & 97,4 & 5 & 2,6 \\
\hline $11-15$ năm & 75 & 98,7 & 1 & 1,3 \\
\hline Trên 15 năm & 2 & 100,0 & 0 & 0 \\
\hline
\end{tabular}

Tỷ lê người bênh đáp ứng điều trị càng cao khi có thời gian điêu trị ARV càng dài. Tỷ lệ đáp ứng điều trị ARV cao nhất trong nhóm có thời gian điêu trị $A R V$ trên 15 năm $(100 \%)$ và thấp nhất trong nhóm dưới 5 năm $(93,1 \%)$, tuy nhiên sự khác biệt này không có ý nghĩa thống kê với p>0,05.

Bảng 3: Thức trang đáp ứng điều trị ARV theo phác đồ điều trị $(n=399)$

\begin{tabular}{|c|c|c|c|c|}
\hline $\begin{array}{c}\text { Phác đồ } \\
\text { điều trị }\end{array}$ & \multicolumn{2}{|c|}{$\begin{array}{c}\text { Dáp ứng điêu } \\
\text { trị ARV }\end{array}$} & \multicolumn{2}{|c|}{$\begin{array}{c}\text { Không đáp ứng } \\
\text { điêu trị ARV }\end{array}$} \\
\hline & $\mathbf{n}$ & $\%$ & $\mathbf{n}$ & $\%$ \\
\hline Bậc 1 & 374 & 96,1 & 15 & 3,9 \\
\hline Bậc 2 & 10 & 100 & 0 & 0 \\
\hline
\end{tabular}

Tỷ lê đáp ứng điều trị ARV trong nhóm người bệnh điều trị theo phác đồ bậc 2 cao hơn nhóm người bệnh điều trị phác đồ bậ̣c 1 . 
người nhiễm HIV đang điều trị tại hai cơ sở chăm sóc điêu trị HIV/AIDS Bệnh viện Đa khoa khu vực Nghĩa Lộ và Trung tẩm $Y$ tế thành phố Yên Bái với một đớn vị là bệnh viện hạng 2 và một trung tâm y tế 2 chức năng vừa làm công tác điêu trị vừa làm công tác dự phòng. Người bệnh chủ yếu nằm trong nhóm 40-49 tuổi và nhóm 30-39 tuổi, chiếm tỷ lệ lần lượt là $50,8 \%$ và $30,6 \%$. Người bệnh chủ yếu là nam giới với $61,2 \%$, phân lớn có trình độ học vấn là trung học phổ thông. Nhóm đối tượng trong nghiên của chúng tôi có đặc điểm nhân khẩu học tương đồng với một số nghiên cứu khác [6-9].

Kết quả xét nghiẹm tải lượng vi rút HIV là phương pháp đầu tiền để đánh giá tình trạng đáp ứng điều trị ARV của người bệnh. Theo hướng dẫn của Bộ Y tế về Điều trị và chăm sóc HIV/AIDS, bệnh nhân đang điều trị bằng thuốc ARV được xét nghiệm thường quy vào thời điểm 6 tháng, 12 tháng kể từ khi bắt đầu điều trị và sau đó được làm xét nghiệm thường quy 12 tháng 1 lần, để theo dõi hiệu quả điều trị [10]. Trong nghiên cứu này, 399 người bênh tham gia đều được làm xét nghiệm tải lượng vi rút HIV trong vòng 12 tháng. Kết quả cho thấy có $96,2 \%$ bệnh nhân đáp ứng điều trị khi có kết quả xét nghiệm tải lượng vi rút dưới 200 bản sao/ml. Điều đó cho thấy rằng có $96,2 \%$ người bênh tham gia nghiên cứu không có đột biến kháng thuốc. Tuy nhiên vẫn cần theo dõi tình trạng điều trị của bệnh nhân để hạn chế các tác dụng phụ của thuốc, từ đó tăng cường việc tuân thủ của bệnh nhân. Tỷ lệ đáp ứng điều trị trong nghiên cứu này cao hơn tỷ lệ đáp ứng điêu trị trung bình trên cả nước và môt số nghiên cứu trên thế giới $[4,6,9]$. Có sự khác biệt này có thể do thuốc điều trị ngày càng được tối ưu hóa, thuận tiện cho bệnh nhân, thời gian ức chế được vi rút nhanh, ít tác dụng phụ nên tăng sự tuẩn thủ điều trị dẫn đến đáp ứng điều trị của bệnh nhân tốt hơn.

Khi phân tích mối tương quan đơn biến, kết quả nghiên cứu cho thấy có mối liên quan giữa đáp ứng điều trị $A R V$ với trình độ học vấn của người bệnh, thời gian điều trị, sự tuần thủ điều trị, các tác dụng phụ mà người bệnh gặp phải và mức độ nhận được sự hỗ trợ từ các cán bộ y tế. Tuy nhiên, khi đưa các yếu tố này vào mồ hình hồi quy đa biến, nghiên cứu chỉ tìm thấy mối liên quan giữa đáp ứng điều trị và trình độ học vấn của người bệnh, thời gian điều trị và sự tuân thủ điều trị. Kết quả nghiên cứu cho thây người bệnh học hết trung học phổ thông có khả năng đáp ứng điều trị gấp 11 lần so với người bệnh có học vấn dưới trung học phổ thông. Người bệnh có trình độ học vấn cao sẽ có xu hướng cập nhật thông tin về điều trị cũng như tuân thủ điều trị hơn, từ đó họ sẽ có đáp ứng điêu trị tốt hơn. Nghiên cứu cũng chỉ ra rằng, người bệnh có thời gian điều trị $A R V$ càng lâu thì sẽ càng có đáp ứng điều trị tốt hơn. Bệnh nhân có thời gian điều trị càng lâu sẽ nhận thức được tầm quan trọng của liệu pháp điều trị, có nhiều kinh nghiệm sử dưng thuốc ARV cũng như nhận được nhiều sự hỗ trợ từ người thân, ban bè. Trong nghiên cứu, tỷ lệ bệnh nhân tuân thủ điều trị là $67,4 \%$, cao hơn so với một số nghiên cứu khác $[7,8]$. Nghiên cứu của chúng tôi chỉ ra rằng người bệnh tuân thủ điều trị có khả năng đáp ứng điều trị ARV cao gấp 3,2 lần so với người bệnh không tuân thủ điều trị. Điều trị ARV đòi hỏi người bệnh phải tuân thủ điều trị nghiêm ngặt về thời gian, liều lượng và cách dùng thuốc. Bệnh nhân tuân thủ điều trị sẽ giúp hạn chế sự nhân lên và xuất hiện các đột biến kháng thuốc của vi rút HIV, từ đó giúp họ có đáp ứng điều trị tốt hơn [8].

\section{KẾT LUÂ̂N}

Nghiên cứu trên 399 người bệnh nhiễm HIV/AIDS đang được quản lý và điều trị ARV cho thây có $96,2 \%$ người bệnh có đáp ứng với điều trị ARV, trong đó $100 \%$ người bệnh sử dụng phác đồ bậc 2 có đáp ứng điều trị. Phân tích các yếu tố liên quan đến đáp ứng điều trị cho thấy: người bệnh có trình độ học vấn là trung học phổ thông có khả năng đáp ứng điều trị cao gấp 11 lần so với người bệnh có học vấn dưới trung học phổ thông. Người bệnh có thời gian điều trị ARV càng lâu thì càng có đáp ứng điều trị ARV hơn nhóm mới điều trị. Người bệnh tuân thủ điều trị có khả năng đáp ứng điều trị cao gấp 3,2 lần so với người bệnh không tuân thủ điều trị.

\section{TÀI LIÊU THAM KHẢO}

1. Eisinger, R., C. Dieffenbach, and A. Fauci, HIV Viral Load and Transmissibility of HIV Infection: Undetectable Equals Untransmittable. JAMA, 2019. 321.

2. Rodger, A.J., et al., Risk of HIV transmission through condomless sex in serodifferent gay couples with the HIV-positive partner taking suppressive antiretroviral therapy (PARTNER): final results of a multicentre, prospective, observational study. Lancet, 2019. 393(10189): p. 2428-2438.

3. UNAIDS. Global HIV \& AIDS statistics - Fact sheet. 2020; Available from: https://www.unaids.org/en/resources/fact-sheet.

4. Cục Phòng chống HIV/AIDS. Báo cáo Tổng kết cống tác Phòng, chống HIV/AIDS năm 2019 và nhiệm vụ trọng tâm năm 2020. 2020; Available from: hittp://vaac.gov.vn/bao-cao-tong-ket-congtac-phong-chong-hiv-aids-nam-2019-va-nhiem-vutrong-tam-nam-2020.html. 
5. Trung tâm Kiểm soát bệnh tật tỉnh Yên Bái. Báo cáo công tác Kiểm soát bệnh tật năm 2020 và phương hướng nhiệm vụ năm 2021. 2020.

6. Bvochora, T., et àl., Enhanced adherence counselling and viral load suppression in HIV seropositive patients with an initial high viral load in Harare, Zimbabwe: Operational issues. PLoS One, 2019. 14(2): p. e0211326.

7. Phạm Xuân Sáng and Phan Thị Thu Hương, Thực trạng và các yếu tố liên quan đến tuân thú điều trị $A R V$ của bệnh nhân tại các phòng khám ngoại trú của tỉnh Điện Biên nằm 2016. Tạp chí Y học dự phòng, 2017. 27(2(190)).

8. Phan Thị Thu Hương, Tuân thủ điêu trị $A R V$ và các yếu tố liên quan trên bênh nhân AIDS đang được điều trị tại trung tâm phòng chống HIV/AIDS tỉnh Hải Dương, năm 2016. Tạp chí Y học dự phòng, 2017. 27(3): p. 194-197.

9. Awungafac, G., et al., Viral load testing and the use of test results for clinical decision making for HIV treatment in Cameroon: An insight into the clinic-laboratory interface. PLoS One, 2018. 13(6): p. e0198686.

\section{KẾT QUẢ ĐIỀU TRI UNG THƯ VÒM MŨI HỌNG GIAI ĐOẠN MUỘN BẰNG PHÁC ĐỒ GEMCITABINE - CISPLATIN TẠI BỆNH VIỆN K}

\section{TÓM TẮT}

Mục tiêu: Đánh giá đáp ứng điều trị và một số tác dung không mong của phác đồ gemcitabine- cisplatin trên nhóm bệnh nhân nghiên cứu. Đối tượng và phương pháp nghiên cứu: Nghiên cứu mổ tả hồi cứu kết hợp với tiến cứu. Có 33 bệnh nhân ung thư vòm giai đoạn muộn được điều trị bước một bằng gemcitabine - cisplatin tại Bệnh viện $K$ từ tháng 1/2018 đến tháng 7/2021, bệnh nhân được đánh giá mức độ đáp ứng theo "Tiêu chuẩn Đánh giá Đáp ứng cho U đặc" (RECIST), độc tính theo tiêu chuẩn CTCAE 5.0. Kết quả: Đáp ứng: Tỉ lệ đáp ứng của phác đồ là 83,9 \%. Trung vị thời gian sổng thêm bệnh không tiến triển là 8,9 tháng. Độc tính: Các tác dung phụ hay gặp bao gồm: hạ bach cầu trung tính $(60.6 \%)$, hạ huyết sắc tố $(90,9 \%)$, nôn buồn nôn $(51.5 \%)$, chủ yếu là độc tính độ I, II. Kết luận: Phác đồ gemcitabine cisplatin cho bệnh nhân ung thư vòm mũi họng tỷ lệ đáp ứng cao, độc tính chủ yếu lên hệ huyết học, dung nạp tốt.

Tư khóa: ung thư vòm mũi họng, giai đoạn tái phát, di căn

\section{SUMMARY \\ EFFICACY OF GEMCITABINE -CISPLATIN IN METASTATIC NASOPHARYNGEAL CANCER PATIENTS IN VIETNAM NATIONAL CANCER HOSPITAL}

Objectives: The aims of our study were to investigate the activity and toxicity of gemcitabine cisplatin regimen in metastatic nasopharyngeal cancer patients. Patients and Methods: Clinical trial, retrospective study. From January 2018 to July 2021,

\footnotetext{
${ }^{1}$ Trường Đại học Y Hà Nội

²Bênh viên $K$ Tân Triều

Chịu trách nhiệm chính: Nguyễn Thị Phương Anh

Email: phuonganhhmu95@gmail.com

Ngày nhân bài: 28.7.2021

Ngày phản biện khoa học: 29.9.2021

Ngày duyệt bài: 4.10.2021
}

\section{Nguyễn Thị Phương Anh ${ }^{1}$, Đỗ Hùng Kiên ${ }^{2}$}

we enrolled 33 metastatic nasopharyngeal cancer patientsin Vietnam National Cancer Hospital. All patients received combination of gemcitabine and cisplatin. Tumor response rateand toxicitys were determined. Results: Response rate: Overal response rate was $83,9 \%$. Median progression free survival was 8,9 months. Toxicity: Most adverse events were manageable and tolerable. The most common was neutropenia $(60.6 \%)$, anaemia $(90.9 \%)$, vomiting and nausea (51.5\%), most of them were grade 1 and grade 2. Conclusion: Gemcitabine cisplatin regimen in metastatic nasopharyngeal cancer patients is high repsond rate and tolerable.

Key words: Nasopharyngeal cancer, recurrent, metastatic stages

\section{I. ĐĂT VẤN ĐỀ}

Ung thư vòm mũi họng (UTVMH) là bệnh lý ác tính có nguồn gốc từ biểu mô vòm mũi họng, là một trong những ung thư phổ biến vùng đầu cổ. Tại Việt Nam, UTVMH đứng thứ 9 về tỉ lệ mới mắc, và thứ 7 về tỉ lệ tử vong ở cả 2 giới, có thể gặp 2 đỉnh tuổi: 15-24 tuổi và độ tuổi 45-60, nam mắc nhiều hơn nữ với một số yếu tố nguy cơ: virut EBV, chế độ ăn, chủng tộc, di truyền [1], [2], [3].

UTVMH giai đoạn muộn (di căn nguyên phát và tái phát di căn xa) thường có tiên lượng xấu, trung vị sống thêm khoảng 10-15 tháng [4], [5]. Điều trị UTVMH giai đoạn muộn, hóa trị nền tảng platinum đóng vai trò chủ đạo. Trong nhiều thập niên, phác đồCisplatin-5FUđược sử dụng rộng rãi điêu trị UTVMH giai đoạn tái phát, di căn, mặc dù trước đó chưa có bằng chứng chứng tó phác đồ nào có ưu thế hơn trong điều trị. Năm 2016, trong nghiên cứu của Li Zhang và cộng sự, phối hợp Gemcitabine và Cisplatin trong điều trị bước 1 UTVMH giai đoạn tái phát, di căn có tỉ lệ đáp ứng (RR), thời gian sống thêm bệnh không tiến 